Руденко А. А., кандидат ветеринарних наук

Луганський національний аграрний університет

\title{
АНАЛІЗ ВИЖИВАННЯ, ВИЗНАЧЕННЯ ПРЕДИКТОРІВ КАРДІАЛЬНОӤ СМЕРТІ, ПРОГНОЗУВАННЯ ЛЕТАЛЬНОСТІ В СОБАК, ХВОРИХ НА КОМБІНОВАНУ МІТРАЛЬНО-ТРИКУСПІДАЛЬНУ НЕДОСТАТНІСТЬ
}

\author{
Рецензент - доктор ветеринарних наук, професор В. Й. Іздепський
}

\begin{abstract}
За результатами множинного аналізу пропориійних інтенсивностей Кокса, незалежними предикторами летального кіния хвороби виявилися лише три параметри, зокрема: наявність набряку легень, стать і функиіональний клас хронічної сериево-судинної недостатності. Розроблена ефективна модель прогнозування летальності хворих собак упродовж однорічного спостереження з урахуванням основних незалежних предикторів. Отримана модель характеризується високим рівнем інформативності (83,1\%), чутливості $(85,4 \%)$ ma специцфіності $(77,8 \%)$.
\end{abstract}

Ключові слова: собаки, комбінована мітрально-трикуспідальна недостатність, вижсиання, прогноз.

Постановка проблеми. Комбінована мітрально-трикуспідальна недостатність (КМТН) у собак виникає на тлі ендокардіозу атріовентрикулярних клапанів серця й призводить до розвитку синдрому хронічної серцево-судинної недостатності (ХCСН) і передчасної загибелі тварин [3, 4, 6-8]. Неабияку практичну цінність має визначення прогностичних маркерів для визначення тривалості життя собак, хворих на КМТН.

Аналіз останніх досліджень і публікацій, у яких започатковано розв'язання проблеми. Предикторами летальності собак, хворих на ендокардіоз атріовентрикулярних клапанів, є наявність асциту та набряку легень [6], ожиріння $[7,8]$, підвищений вміст N-термінального фрагменту пронатрійуретичного пептиду типу В [3, 4], серцевого тропоніну I [5], зменшення величини серцевого індексу, концентрації сечовини і розмір лівого передсердя [6]. Зауважимо, що багато аспектів виживання й прогнозування перебігу собак, хворих на КМТН, залишаються допоки що маловивченими.

Мета роботи - визначити незалежні предиктори кардіальної смерті; розробити логістичну модель прогнозу летальності в собак, хворих на КМТН.

Завдання: розробити ефективну модель прогнозування летальності хворих собак; дослідити їх виживання упродовж однорічного спостереження 3 урахуванням основних незалежних предикторів.

Матеріали і методи. Для оцінки виживання застосовували метод Каплана-Мейера. Порівняння груп проводили за допомогою критерію Гехана. Предиктори смерті визначали за допомогою аналізу пропорційних інтенсивностей Кокса. Спочатку проводився аналіз впливу кожного окремого показника на час від початку спостереження до виникнення події (уніваріантний аналіз). Визначалося відношення ризиків (hazard ratio) - HR. Після цього створювалася модель множинного аналізу, до якої за загальноприйнятою методикою залучалися всі показники, які за даними уніваріантного аналізу вірогідно впливали на виникнення події $(\mathrm{p}<0,05)$. Показники, які при множинному аналізі достовірно впливали на виникнення кінцевої події, визначалися як незалежні предиктори цієї події. Чутливість і специфічність методів прогнозування летального кінця хвороби розраховували за стандартними методиками. Усі розрахунки проводили на персональному комп'ютері за допомогою статистичної програми STATISTICA 7.0 (StatSoft, USA) [1, 2].

Результати дослідження. Аналіз виживання, визначення предикторів кардіальної смерті, прогнозування летальності в собак був проведений на 59 собаках, хворих на КМТН. Із них 35 псів та 24 сук, середній вік становив $11,1 \pm 0,4$ роки. Тривалість спостереження становила в середньому $281,7 \pm 29,8$ дня (17-1049), що відповідає $0,8 \pm 0,1$ року. Середній ФК ХССН - 2,4士0,1. Упродовж першого року спостереження загинула 41 тварина (69,5 \%). Усі випадки серцевої смерті були поділені на смерть від прогресування ХССН - 51 (86,4 \%) та раптову смерть - $8(13,6 \%)$ хворих собак.

Результати аналізу щодо визначення предикторів кардіальної смерті у собак, хворих на КМТН (табл. 1). До аналізу пропорційних інтенсивностей Кокса були залучені наступні параметри: стать, вік, маса тіла, наявність ціанозу, переповнення яремних вен кров'ю, набряку легень, 
асциту, ФК ХССН, температура тіла, ЧСС, ЧДР, швидкість наповнення капілярів кров'ю (ШНКК), тривалість зубця $\mathrm{P}$, інтервалів PQ, QRS, QT, кінцево-діастолічний розмір (КДР), кінцево-систолічний розмір (КСР), кінцеводіастолічний об'єм (КДО), кінцево-систолічний об’єм (КСО), фракція викиду (ФВ), розмір лівого передсердя (ЛП), вміст гемоглобіну, еритроцитів, лейкоцитів, ШОЕ, активність АлАТ, АсАТ, концентрація сечовини і креатиніну. До таблиці 1 внесені лише показники, відношення ризиків (HR) для яких виявилося достовірним $(\mathrm{p}<0,05)$.

\section{1. Предиктори кардіальної смерті у собак, хворих на комбіновану} мітрально-трикуспідальну недостатність

\begin{tabular}{|c|c|c|c|c|}
\hline \multirow{2}{*}{ Предиктор } & \multicolumn{3}{|c|}{ Вид аналізу пропорційних інтенсивностей Кокса } \\
\cline { 2 - 5 } & \multicolumn{2}{|c|}{ уніваріантний } & $\mathrm{HR}$ & $\mathrm{p}$ \\
\cline { 2 - 5 } & $\mathrm{HR}$ & $<$ & 4,21 & $<0,001$ \\
\hline Набряк легень & 4,71 & $<0,001$ & 2,21 & $<0,5$ \\
\hline Асцит & 9,56 & $<0,001$ & 2,03 & $<0,01$ \\
\hline ФК ХССН & 1,93 & $<0,001$ & 5,32 & $<0,001$ \\
\hline Стать & 2,91 & $<0,05$ & 1,02 & $<0,5$ \\
\hline ЧДР & 1,03 & $<0,05$ & 2992,3 & $<0,5$ \\
\hline КДР & 3,29 & $<0,05$ & 1,62 & $<1$ \\
\hline КСР & 2,10 & $<0,05$ & 0,69 & $<0,5$ \\
\hline КДО & 1,05 & $<0,05$ & 0,95 & $<1$ \\
\hline КСО & 1,05 & $<0,05$ & 0,79 & $<1$ \\
\hline ЛП & 1,72 & $<0,05$ & 0,02 & $<0,1$ \\
\hline Креатинін & 0,02 & & & \\
\hline
\end{tabular}
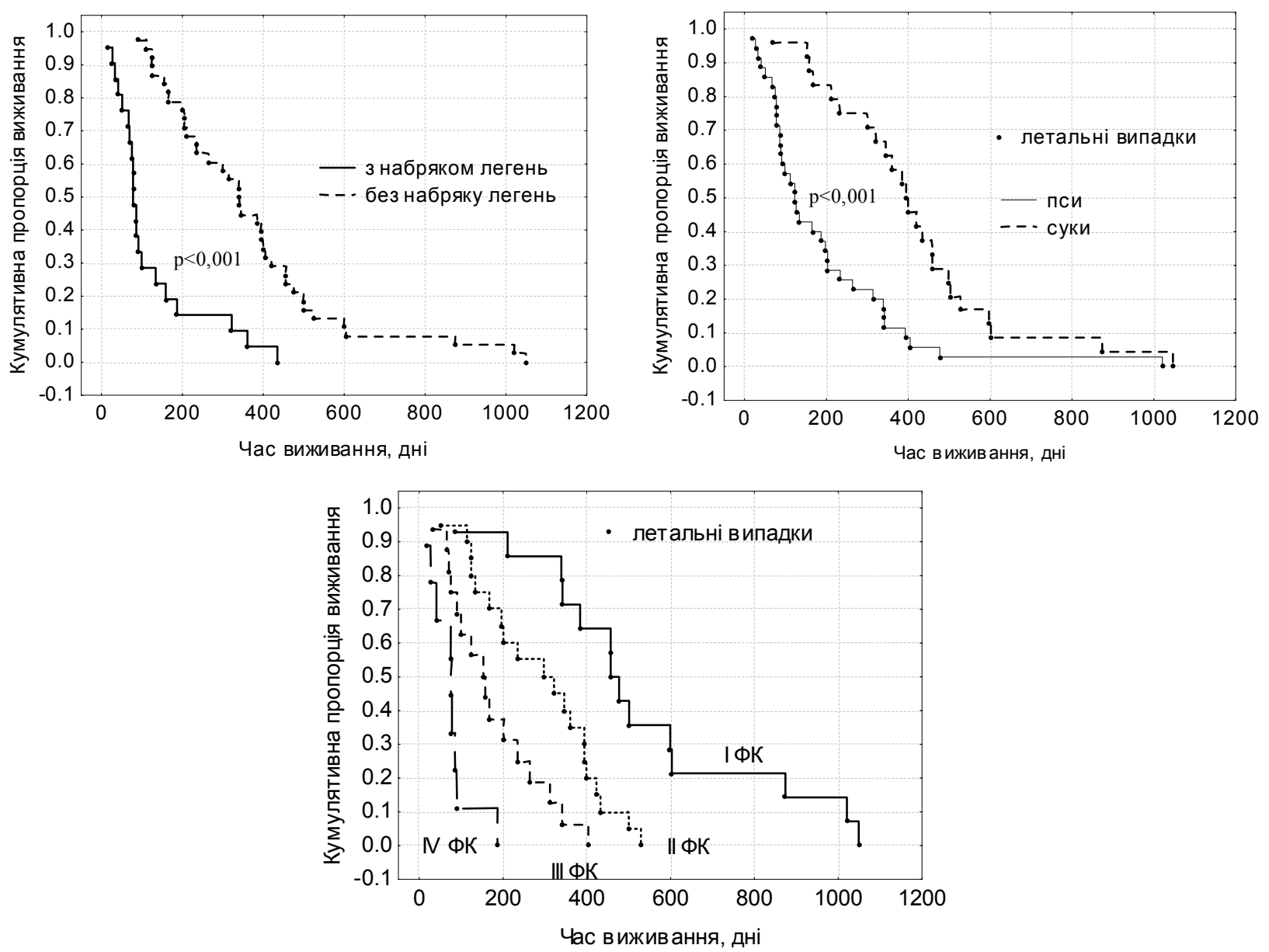

Рис. Кумулятивна пропорція виживання собак, хворих на КМТН, залежно від впливів незалежних клінічних предикторів 


\section{2. Результати прогнозування виживання собак, хворих на КМТН}

\begin{tabular}{|c|c|c|c|}
\hline Групи хворих тварин & $\begin{array}{c}\text { Правильні відповіді } \\
\text { системи }\end{array}$ & $\begin{array}{c}\text { Неправильні відповіді } \\
\text { системи }\end{array}$ & Усього хворих \\
\hline Собаки, які вижили & $14(77,8 \%)$ & $4(22,2 \%)$ & 18 \\
\hline Собаки, які вмерли & $35(85,4 \%)$ & $6(14,6 \%)$ & 41 \\
\hline Усього & $49(83,1 \%)$ & $10(16,9 \%)$ & 59 \\
\hline
\end{tabular}

Установлено, що більшість клініко-інструментальних показників (наявність набряку легень, асциту, стать, ФК ХССН, ЧДР, КДР, КСР, КДО, КСО, ЛП, креатинін) асоціювалися зі збільшенням ризику смерті при проведенні уніваріантного аналізу. За результатами множинного аналізу пропорційних інтенсивностей Кокса, незалежними предикторами летального кінця хвороби виявилися лише наявність набряку легень, стать i ФК ХССН.

Як видно з рисунка, найгіршим прогнозом характеризується когорта хворих тварин із наявністю набряку легень.

Так, за тестом Гехана виявили, що тварини, хворі на КМТН, ускладнену набряком легень, мали вірогідно $(\mathrm{p}<0,001)$ нижчі показники виживання, ніж хворі собаки без явищ гіперемії та набряку легень.

Аналіз отриманих даних із використанням методу Каплана-Мейера показав наявність вірогідної різниці у виживанні собак, хворих на КМТН, залежно від їх статі. Відчутно гіршим виживанням характеризуються самці, про що свідчать результати тесту Гехана $(\mathrm{p}<0,001)$.

Оцінка кумулятивних кривих виживання - за методом Каплана-Мейера - собак, хворих на КМТН, показала наявність вірогідної різниці у виживанні хворих залежно від градації ФК $\mathrm{XCCH} \mathrm{у} \mathrm{процесі} \mathrm{первинного} \mathrm{обстеження.}$

Виживання хворих собак вірогідно знаходиться у зворотній залежності за градації ФК ХССН. Нижчі показники виживання у хворих собак, які за первинного огляду мали III-IV ФК ХCCH.

Для прогнозування летального кінця хвороби в собак, хворих на КМТН, впродовж 1-го року спостереження був застосований метод множинної логістичної регресії з урахуванням усіх незалежних предикторів, що впливають на виживання, зокрема, наявність набряку легень, стать i ФК ХССН.

Для побудови моделі логістичної регресії, що описувала характер перебігу ХССН у собак, хворих на КМТН, були використані два масиви даних: перший об'єднував собак ( $\mathrm{n}=41)$, які померли впродовж 12 місяців спостереження, і другий - пацієнтів ( $\mathrm{n}=18)$, які прожили понад рік. Зага- льна кількість пацієнтів, які ввійшли до аналізу, - 59. У ході аналізу була отримана наступна регресійна модель:

$$
y=\frac{1}{1+\exp (2,23-2,28 \times H J-2,21 \times C m-0,67 \times \Phi K)}
$$

де: у - вихідний параметр моделі; 2,23 - вільний коефіцієнт; НЛ - наявність набряку легень; Ст - стать; ФК - ФК ХССН виражений в умовних одиницях.

Достовірність моделі (1) проаналізована за допомогою критерію Фішера та коефіцієнта множинної кореляції (R). Проведений аналіз показав, що множинна кореляція була досить високою $(\mathrm{R}=0,84 ; \mathrm{p}<0,001)$. Стандартна похибка моделі становила 1,07 . Критерій $\chi^{2}$ моделі дорівнював 26,3 за найвищого рівня вірогідності отриманих результатів $(\mathrm{p}<0,001)$.

Оцінка ефективності моделі (1) проведена на 96-и тваринах, хворих на МН, ускладнену синдромом ХССН різних ФК (табл. 2).

У разі значення вихідного параметру $\mathrm{y} \geq 0,5$ кінець захворювання розцінювали як несприятливий і при $\mathrm{y}<0,5$ - як сприятливий щодо виживання впродовж одного року. Варто також зазначити, що отримана модель характеризувалася високим рівнем інформативності $(83,1 \%)$, чутливості $(85,4 \%)$ і специфічності $(77,8 \%)$. До того ж вкрай важливо, що в 83,1 \% випадків модель давала змогу надати вірний прогноз перебігу $\mathrm{XCCH}$.

Поєднання високої чутливості 3 менш високою специфічністю свідчило, що прогнозування дещо відхилялося в бік гіпердіагностики випадків із несприятливим прогнозом. Таким чином, отримані дані доводять, що певний відсоток хворих тварин не враховується як потенційні випадки 3 можливим сприятливим кінцем хвороби.

\section{Висновки:}

1. За результатами множинного аналізу пропорційних інтенсивностей Кокса, незалежними предикторами летального кінця хвороби виявилися тільки три параметри, а саме: наявність набряку легень, стать і функціональний клас хронічної серцево-судинної недостатності. 
2. Розроблено ефективну модель прогнозування летальності хворих собак упродовж однорічного спостереження з урахуванням основних незалежних предикторів. Отримана модель характеризується високим рівнем інформативності $(83,1 \%)$, чутливо-

\section{БІБЛІОГРАФІЯ}

1. Боровиков В. П. STATISTICA: искусство анализа данных на компьютере. Для профессионалов. 2-е изд. $(+\mathrm{CD}) /$ В. П. Боровиков. - СанктПетербург : Питер, 2003. - 688 с.

2. Реброва О. Ю. Статистический анализ медицинских данных. Применение пакета прикладных программ STATISTICA / O. Ю. Реброва. М. : Меди Сфера, 2002. - 312 c.

3. Analytical, physiologic, and clinical validation of a radioimmunoassay for measurement of procollagen type III amino terminal propeptide in serum and bronchoalveolar lavage fluid obtained from dogs / S. Schuller, S. Valentin, B. Remmy [et al.] // Am. J. Vet. Res. - 2006. - Vol. 67 (5). - P. 749-755.

4. Association of plasma N-terminal pro-B-type natriuretic peptide concentration with mitral regurgitation severity and outcome in dogs with asymptomatic degenerative mitral valve disease / V. Chetboul, F. Serres, R. Tissier [et al.] // J. Vet. Intern. сті (85,4\%) та специфічності (77,8 \%).

3. Перспективним напрямом досліджень $є$ вивчення впливу різних схем лікування на виживання i прогноз собак, хворих на серцевосудинні захворювання.

Med. - 2009. - Vol. 23 (5). - P. 984-994.

5. Cardiac troponin I as a marker for severity and prognosis of cardiac disease in $\operatorname{dogs} / \mathrm{S}$. Fonfara, J. Looureiro, S. Swift [et al.] // Vet. J. - 2009. - P. 33.

6 . Chordae tendinea rupture in dogs with degenerative mitral valve disease: prevalence, survival, and prognostic factors (114 cases, 2001-2006) / F. Serres, V. Chetboul, R. Tissier [et al.] // J. Vet. Intern. Med. - 2007. - Vol. 21 (2). - P. 258-264.

7. Diagnostic potential of natriuretic peptides in the occult phase of golden retriever muscular dystrophy cardiomyopathy / [V. Chetboul, D. Tessier-Vetzel, C. Escrioou et al.] // J. Vet. Intern. Med. - 2004. Vol. 18 (6). - P. 845-850.

8. Influence of left atral enlargement and body weight on the development of atrial fibrillation: retrospective study / Gugliemini C., Chetboul V., Pietra M. [et al.] // Vet. J. - 2000. - Vol. 160 (3). P. 235-241. 